\title{
Variations of Salminus hilarii diet (Ostariophysi, Characidae): seasonal and ontogenetic effects
}

\author{
Villares Junior, GA. ${ }^{a *}$ and Goitein, R. $^{a}$ \\ aDepartamento de Zoologia, Instituto de Biociências, Universidade Estadual Paulista "Júlio de Mesquita Filho" - UNESP, \\ Avenida 24-A, 1515, CP 199, CEP 13506-900, Rio Claro, SP, Brazil \\ *e-mail: villaresjunior@hotmail.com
}

Received: October 1, 2013 - Accepted: March 10, 2014 - Distributed: August 31, 2015

(With 5 figures)

\begin{abstract}
This study described the variations seasonal and ontogenetic of Salminus hilarii diet. Samples were collected in the Sorocaba River, São Paulo, Brazil, one of the few rivers where individuals of the species still occur in a higher frequency. The preys consumed were analyzed by Importance Alimentary Index (AIi). To determine similarities between year seasons, the AIi data were analyzed by the Morisita-Horn index and reduced in cluster analysis, along with a statistical comparison made by one-way ANOSIM test (5\%). The feeding activity was analyzed according to the stomach repletion index and compared among the year seasons using non parametric variance analysis Kruskal-Wallis test (5\%). Comparison of prey consumed between immature and adult individuals was made by Spearman correlation (5\%). A Pearson correlation (5\%) was applied between the standard length of the fish and prey consumed, as well as between the mouth and prey heights. The analyzes of stomach contents showed that the diet of this species was exclusively piscivorous, with significant difference of prey consumption during the period, the same happening among adult and immature individuals. It was observed that these fishes use to swallow their prey whole and that significant correlations between size of predator and prey size can be observed. There is also correlation between the mouth height and the maximum prey depth. Salminus hilarii feeds on the available prey, and the species food composition and feeding activity depends on prey`s abundance, their size and morphology, as do the water temperatures.
\end{abstract}

Keywords: piscivorous, feeding activity, seasonality, ontogeny, Sorocaba river.

\section{Variações na dieta de Salminus hilarii (Ostariophysi, Characidae): efeitos da sazonalidade e ontogenia.}

\begin{abstract}
Resumo
Este estudo descreve as variações na dieta de Salminus hilarii em relação aos efeitos da sazonalidade e da ontogenia. As coletas foram realizadas no rio Sorocaba, São Paulo, Brasil, um dos poucos rios onde a espécie ainda é encontrada com frequência. As presas consumidas foram analisadas pelo índice de importância alimentar (AIi). Para determinar similaridades entre as estações do ano, os dados do AIi foram analisados pelo índice de Morisita-Horn e reduzidos em uma análise de agrupamento, em associação com uma comparação estatística realizada pelo teste one-way ANOSIM (5\%). A atividade alimentar foi analisada pelo índice de repleção estomacal e comparada entre as estações do ano usando o teste de variância não paramétrico de Kruskal-Wallis (5\%). A comparação das presas consumidas entre os indivíduos imaturos e adultos foi feita pela correlação de Spearman (5\%). Uma correlação de Pearson (5\%) foi aplicada entre o comprimento padrão do peixe e da presa, assim como entre a altura da boca e a altura da presa. As análises dos conteúdos estomacais mostraram que a dieta dessa espécie foi exclusivamente piscívora, com diferença significativa do tipo de presas consumidas ao longo do ano e entre adultos e imaturos. Foi observado que esta espécie engole as presas inteiras com correlações significativas entre o tamanho do predador e presa e, também entre a altura da boca e altura da presa. Salminus hilarii consome as presas disponíveis no ambiente sendo que, a composição da dieta e a atividade alimentar dependem da abundância, tamanho e morfologia das presas, além da temperatura da água.
\end{abstract}

Palavras-chave: piscívoro, atividade alimentar, sazonalidade, ontogenia, rio Sorocaba.

\section{Introduction}

The diet analysis is important for studies about predation, competition and food chains, as it permits the access to the knowledge about fish feeding ecology (Costello, 1990).
Fish feeding behavior is the consequence of evolutionary sequences, which result in the establishment of the alimentary spectrum presented by each species, in the order to select, 
capture and digest a particular food type, and helps one to understand to figure out aspects related to the roles the several species play within the environment.

Though a feeding specificity may be commonly described for fish studies, such diets may vary considerably according to the sites, year season and food availability. Seasons may influence feeding rhythms as temperatures vary and even when some activities occur during the day or night, as food resources may occur at distinct compositions (Zavala-Camin, 1996).

During the process of ontogeny fish changes the feeding composition and a new spectrum may occur. This fact may be directly related to changes in its morphological structure (Wainwright and Richard, 1995; Lowe-McConnell, 1999; Bozza and Hahn, 2010). The study of functional anatomy related to the feeding of fishes may bring basic information concerning occupation of ecological niches and their adaptation to such occupation. Morphological and behavioral traits related to prey capture and predator avoidance regulate predator-prey interactions, thus influencing the structure of fish communities (Lowe-McConnell, 1999).

Salminus hilarii Valenciennes, 1850 is a typical predator fish found in rapid flowing streams and rivers. The individuals of the species are distributed in several South American river basins: Paraná, São Francisco, some rivers in the Amazon basin, Tocantins, and Orinoco (Lima et al., 2003). It is considered as a rheophilic fish species whose individuals migrate during the reproductive period, coinciding with warmer waters and rainy seasons (Agostinho et al., 2004; Olarte and Taphorn, 2006; Takahashi, 2006; Villares-Júnior et al., 2007; Honji, 2007; Honji et al., 2011).

The species is currently affected by the construction of dams, industrial and domestic pollution and deforestation of riparian vegetation. (Graça and Pavanelli, 2007; Honji, 2007; Honji et al., 2011). So, the importance of knowledge about feeding habits of $S$. hilarii is evident, since this species is one of those ones heavily threatened in South America. This paper will possibly contribute as an information basis for the understanding about the ecology of the species in question, seeking ways to prevent its local extinction.

Considering the ecological importance of $S$. hilarii and the lack of data referring to their diet, this study was carried out to characterize the diet of this species focusing to answer the following questions: i) which are the most important prey to its diet? ii) are there seasonal variations in feeding activity and type of prey? iii) is there a diet ontogenetic variation in diet?

\section{Material and Methods}

The site chosen for the study was the Sorocaba River basin, which is one of the few rivers where the species is still found frequently. The Sorocaba River basin is located in the São Paulo state, Brazil, which is part of the high Parana river basin.

The samples were collected in the lower part of the Sorocaba River basin $\left(23^{\circ} 08^{\prime} 59^{\prime \prime} \mathrm{S}\right.$ and $47^{\circ} 49^{\prime} 08^{\prime \prime} \mathrm{W}$; $23^{\circ} 17^{\prime} 39^{\prime \prime} \mathrm{S}$ and $47^{\circ} 46^{\prime} 32^{\prime \prime} \mathrm{W} ; 2^{\circ} 19^{\prime} 41^{\prime \prime} \mathrm{S}$ and $\left.47^{\circ} 46^{\prime} 50^{\prime \prime}\right)$ (Figure 1). In this site the Sorocaba river width attains 50 meters, its depth varying between 0.50 to 6 meters, and it is one of the few rivers in high Paraná River basin considered to retain all the conditions for maintaining S. hilarii (Villares-Júnior et al., 2007, 2011), with low pollution, riparian forests more preserved and diverse environments (Villares-Júnior and Goitein, 2006).

The sampling was performed monthly between April 2004 and November 2006 at three collection sites. Exemplars were captured using gillnets with different

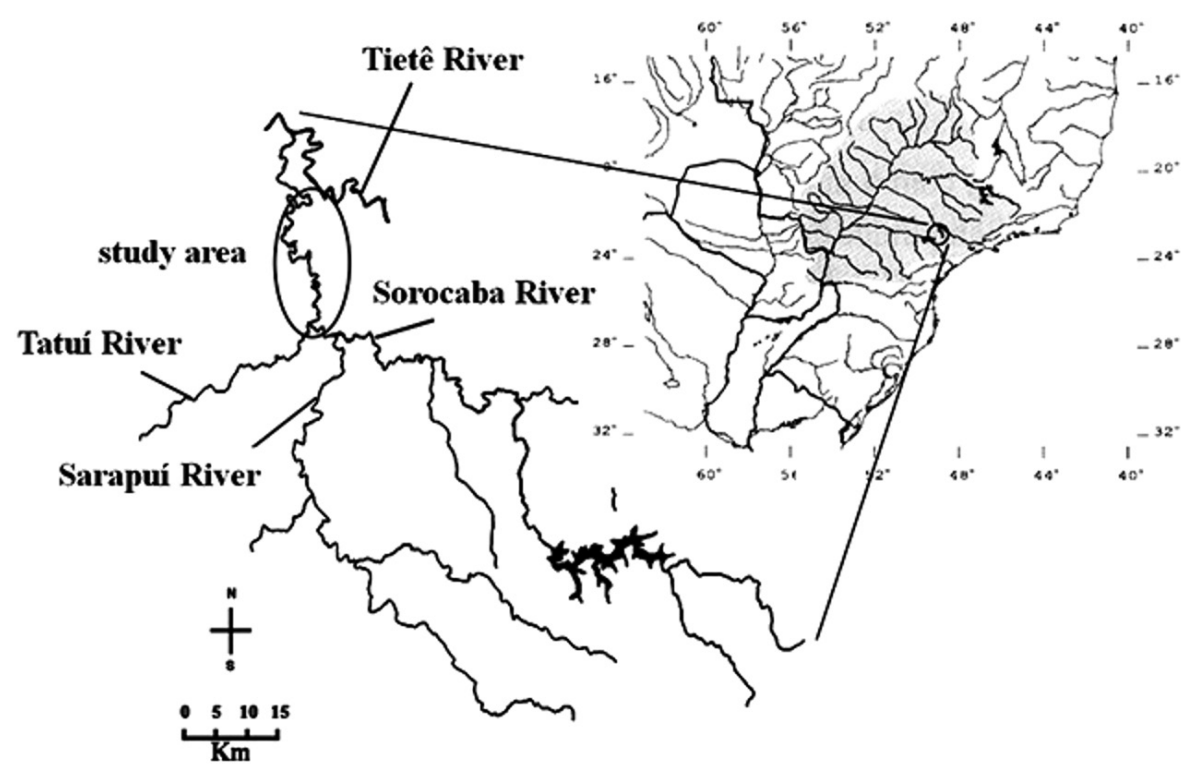

Figure 1. Partial map of South America showing the Alto Paraná river basin and location of Sorocaba river basin with localization of the study area. 
mesh sizes ( 3.0 to $8.0 \mathrm{~cm}$ between opposite knots), with fishing effort of $150 \mathrm{~m}^{2}$ in each site, and complemented with the use of reels and artificial baits in order to avoid the mask of stomach contents. The gill nets were placed in the vicinity of rapid flowing water and maintained for approximately 12 hours and examined every 3 hours during a day. When fishing with artificial baits the cast occurred in rapid waters, where it is impossible to set gillnets.

During the manipulation, the following biological measurements were made: total fish mass, and stomach content mass in grams $(0.01 \mathrm{~g})$; fish (SL) and prey (SLp) standard lengths: distance between the extremity the head until the end of caudal-peduncle spot; depth of prey (Hp): distance in the highest perpendicular height point to the longitudinal axis of stomach contents with lower digestion level; mouth height $(\mathrm{MH})$ : dorsal-ventral length of mouth opening when mouth is completely open. Morphological data were measured in millimeters. Another aspect studied was related to the ontogenetic aspects: immature and adult individuals. The differentiation of individuals was obtained by direct gonads visual inspection following Vazzoler (1996).

Data analysis. The stomach contents were removed and identified under a stereomicroscope to the lowest possible taxonomic level. The preys were analyzed using the Importance Alimentary Index (AIi) proposed by Lima-Júnior and Goitein (2001). This index was calculated using the the formula: $\mathrm{AI}=\mathrm{Fi} * \mathrm{Vi}$, where $\mathrm{Fi}=$ Frequency of Occurrence (Hyslop, 1980) and Vi= Volumetric Analysis index. The Volumetric Analysis index indicates the relative abundance of a particular item found in the stomach samples (Lima-Júnior and Goitein, 2001). How the immature individuals were captured only between late summer and autumn, the analysis of seasonality was made using only adult individuals. A multivariate approach was used to determine the similarity patterns in the diet among the seasons, which were defined as: autumn (March, April and May), winter (June, July and August), spring (September, October and November) and summer (December, January and February). The Morisita-Horn index (Krebs, 1998) was used to the AIi values and similarity food matrix was reduced by using the cluster analysis, and Euclidean distance algorithm. For the statistical comparison among seasons we employed the one-way ANOSIM, using the software PAST 2.15 (Hammer et al., 2001), and the significance level adopted was $5 \%$.

The feeding activity was evaluated according to the stomach repletion index: RI $=$ We* 100/Wt (Hyslop, 1980), where: RI: stomach repletion index; We: total weight mass of stomach content in grams (with approximation tof $0.01 \mathrm{~g}$ ); $\mathrm{Wt}$ : total weight mass of fish in grams (with approximation to $0.01 \mathrm{~g}$ ). Data were not obtained as homogeneous variances, the results obtained by adults were compared among the year seasons using non parametric variance analysis Kruskal-Wallis test (5\%). In addition, the water temperature (were also done monthly, complementing the information regarding life and feeding activities. The statistics analyzes were performed using Statistica 7.1 software (Statsoft, 2005).

The Spearman's ( $r$ ) coefficient was used with significance level of 5\% (Fritz, 1974), and was adopted to compare the items consumed (AIi) between adult and immature individuals. This test was adopted because the data did not showed normal distribution. A Pearson (5\%) correlation was applied between standard length of the fish and standard length of ingested prey, as well as between mouth height and maximum depth of ingested prey.

\section{Results}

During the collecting period, 198 individuals of Salminus hilarii were captured, by using gill nets to 139 of them and 59 by artificial baits. Adults were more abundant $(\mathrm{n}=150)$ in relation to immature individuals $(\mathrm{n}=48)$. The diet of $S$. hilarii was composed exclusively of fishes. In most of stomachs with food it was observed only an entire fish occupying the total space of the stomach. Six food items were identified: Astyanax aff. fasciatus (Cuvier, 1829); Astyanax altiparanae Garutti \& Britski 2000; Poeciliidae; Serrapinnus sp., Pimelodella sp. and indeterminate fish (Table 1). By using cluster analysis distinct patterns were observed to constitute of the diet

Table 1. Importance Alimentary Index (AIi) of adults of Salminus hilarii obtained in each year season in the Sorocaba river basin.

\begin{tabular}{|c|c|c|c|c|c|c|c|}
\hline & & A. aff. fasciatus & A. altiparanae & Pimelodella sp. & Poeciliidae & Serrapinus sp. & Indeterminate \\
\hline \multirow{3}{*}{ 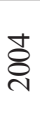 } & Autumn & 1093 & 262.5 & 328.12 & - & - & 625 \\
\hline & Winter & 375 & - & 468.75 & - & - & 2252.2 \\
\hline & Spring & 893.45 & 82.25 & 439.72 & - & - & 945.45 \\
\hline \multirow{4}{*}{ ஜి } & Summer & 1365 & 284 & 30 & 30 & 63 & 621 \\
\hline & Autumn & 2873 & 162.4 & 171.1 & - & - & 220.05 \\
\hline & Winter & 471.87 & - & 473.12 & - & - & 1725 \\
\hline & Spring & 1248.9 & 46.12 & 256.87 & - & - & 1335.2 \\
\hline \multirow{4}{*}{ రి } & Summer & 999 & 626.25 & - & - & 83.65 & 62.5 \\
\hline & Autumn & 2320 & 875 & - & - & - & 249.75 \\
\hline & Winter & 5508 & - & 465 & - & - & 2266.9 \\
\hline & Spring & 3153.2 & 540.5 & - & - & - & 308 \\
\hline
\end{tabular}


between the seasons. Besides this fact, the ANOSIN test revealed significant differences among seasons $(R=0.9852$, $\mathrm{P}<0.01)$. This difference was observed mainly during the winter when the highest frequencies of indeterminate fishes were observed, with high digestion levels. During the other seasons the amount of prey presented a low variation among the consumed items (Figure 2).

The Kruskal-Wallis test analysis for Repletion Index presented a difference for the alimentary activity when distinct seasons were compared $(\mathrm{H}=27.4243, \mathrm{p}<0.01)$. During the winter, when water temperature decreases, food consumption rates are lower. Due to the raising water temperature (Figure 3), an increase in feeding activity of S. hilarii was noticed. The autumn is the season to present higher RI (median values)(Figure 4).

A significant difference in the diet of adult and immature individuals was noticed ( $\mathrm{rs}=0.4554, \mathrm{p}>0.05)$. Astyanax altiparanae showed to be the most representative prey in the diet of immature individuals. Adult individuals showed higher prey diversity in their diet, though Astyanax aff. fasciatus happened to be the most important item (Table 2).

Twenty-six stomach contents with a low level of digestion were measured, and significant correlations

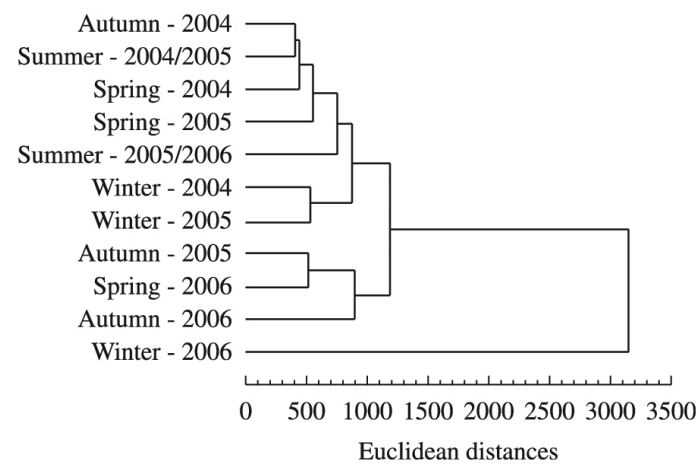

Figure 2. Representation of the similarity patterns in the seasonal diet frequency of adults of Salminus hilarii in the Sorocaba River basin.

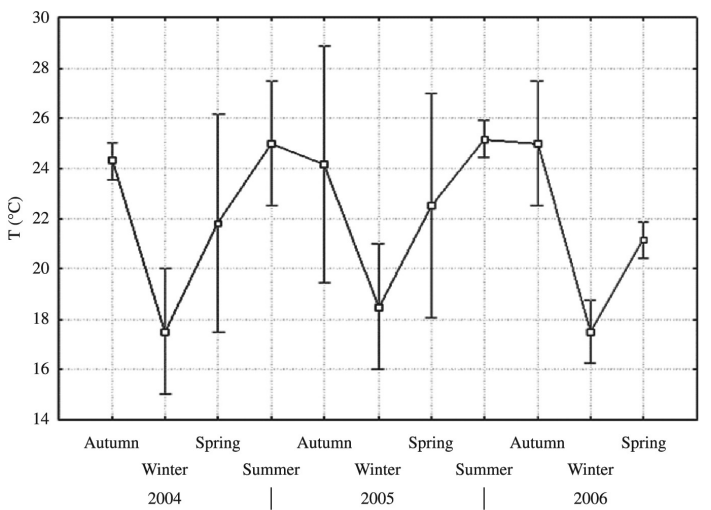

Figure 3. Average water temperature $\left({ }^{\circ} \mathrm{C}\right)$ of Sorocaba River basin during 2004, 2005 and 2006.
(Pearson $\alpha=0.05, \mathrm{p}<0.0001$ ) were observed between predator size and prey size $(r=0.7452)$ (Figure 5a) and between mouth height and prey height $(r=0.8294)$; this one seems to be more coherent for the analysis of amplitude of prey sizes for the respective sizes of $S$. hilarii (Figure 5b).

\section{Discussion}

The diet of piscivorous fish includes a great variety of prey, which reflects their relative abundance in the environment (Dei Tos et al., 2009). Previous studies revealed that Astyanax aff. fasciatus is the species more abundance in the Sorocaba River basin (Smith et al., 2003). The higher frequency of prey belonging to the Astyanax genus reinforces the general recognition that they are most frequent and abundant fish in Neotropical rivers, living in a great diversity of environments; they are omnivorous and very active (Britski et al., 1988), serving as food for a great number of predators (Smith, 2003; Bozza and Hahn, 2010).

The feeding activity during the year seasons, estimated from the stomach repletion indexes, defines with better accuracy the time during which the fish present better feeding conditions (Raposo and Gurgel, 2003). It was noticed that the period showing highest feeding activity was concentrated in the warmer seasons of the year.

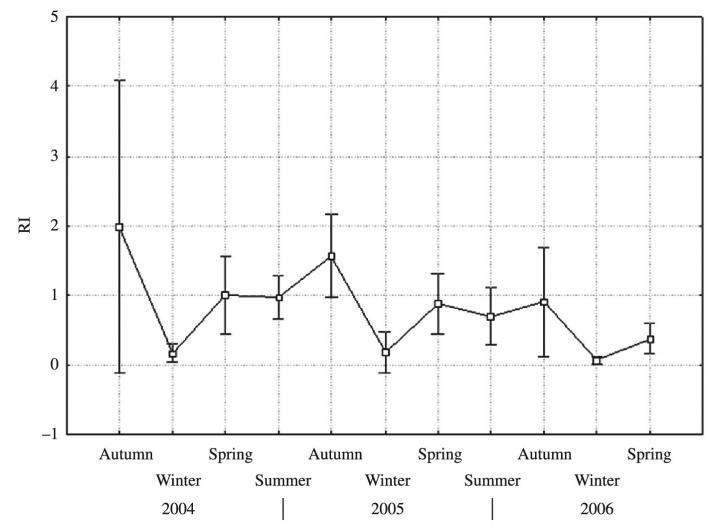

Figure 4. Means and confidence interval of Repletion Index (RI) of adults of Salminus hilarii in Sorocaba River basin during 2004, 2005 and 2006.

Table 2. Importance Alimentary Index (AIi) obtained for immature and adult individuals of Salminus hilarii in the Sorocaba river basin.

\begin{tabular}{ccc}
\hline & immature & adult \\
\hline Astyanax aff. & 295.10 & 1790.32 \\
fasciatus & & \\
Astyanax altiparanae & 2405.00 & 61.50 \\
Pimelodella sp. & - & 180.0 \\
Poeciliidae & - & 0.60 \\
Serrapinnus sp. & - & 4.5 \\
Indeterminate & 800.00 & 770.35 \\
\hline
\end{tabular}



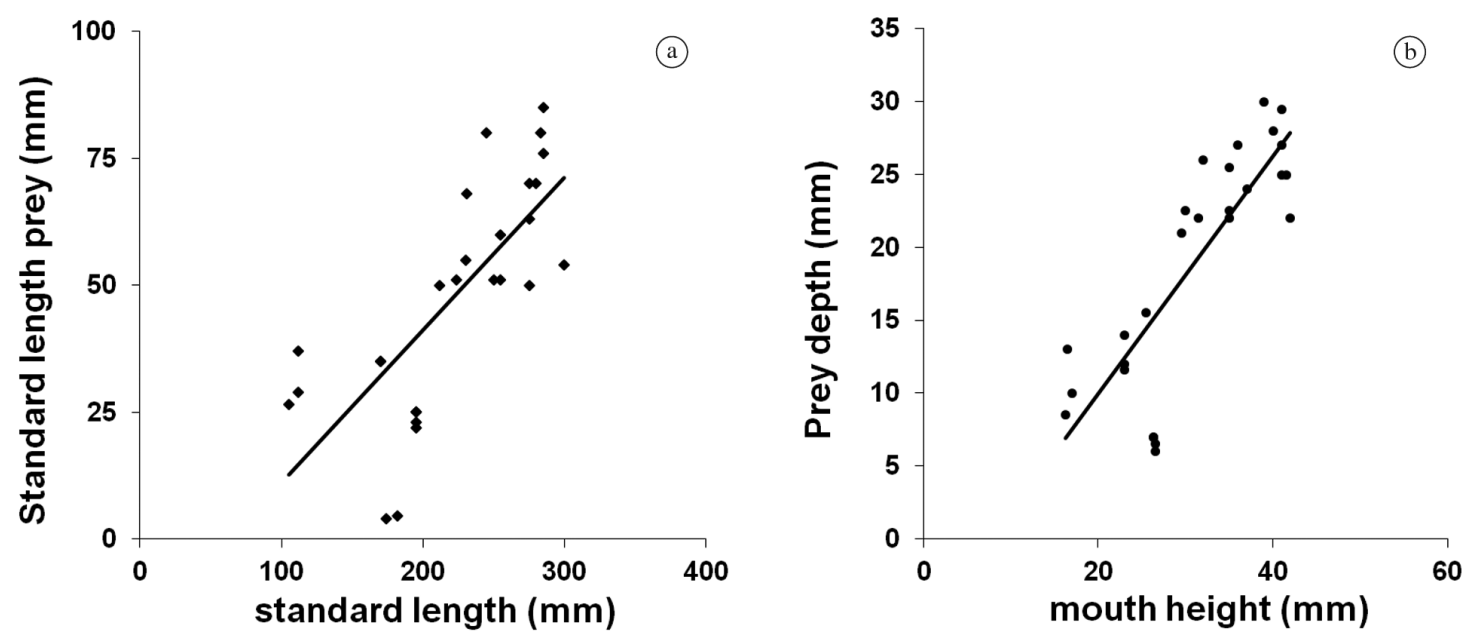

Figure 5. Correlations between: (a) predator and prey length $(\mathrm{p}<0.0001, \mathrm{r}=0.7452)$ and, (b) predator mouth height and prey depth $(\mathrm{p}<0.0001, \mathrm{r}=0.8294)$.

With the temperature elevation, there is tendency for increasing the digestion level due to a more accelerated digestion (Jobling, 1993). For S. hilarii, there is also the moment of acquiring energetic reserves for the reproduction that happens between the end of spring and summer (Takahashi, 2006; Villares-Júnior et al., 2007). The highest food consumption observed during autumn is related to the recovery of reserves spent for the reproduction and to acquire energetic reserves for the winter, when lower RI values were observed. In low temperature periods, fish tend to increase intervals between one ingestion and the other (Zavala Camin, 1996) due to a decrease in metabolism and slower action of the gastric juice, which should the stomach contents to stay longer inside the stomach. Fish feeding activity may suffer variations due to several environmental factors, and these factors may differ according to the characteristics of the environment and the species (Hahn et al., 1997).

Another fact to be pointed out is their availability and easiness for capture. Astyanax aff. fasciatus and Pimelodella sp. tends to occupy central areas in the riverbed (personal observation), where adult individuals of $S$. hilarii use to be more common, being so in the better situation to predate them, unlike $A$. altiparanae that usually lives near the marginal vegetation, a fact to explain a higher frequency of this item within the stomach contents for immature individuals which are commonly found at these site. Piet (1998) alerts that many authors have ignored the influence of intra-specific variations in the division of feeding resources. Direct differences between two classes of sizes to Salminus may indicate a distinct feeding strategy between shoals of fish of different sizes (Olarte and Taphorn 2006; Bozza and Hahn, 2010). Differences in body size are the main means through which species avoid overlapping for resources uses within the environment, by the evolutionary abilities they have developed for the use of resources and avoiding the risks of predation (Werner and Gilliam, 1984).

Changes of the diet composition may have occurred due to a modification in the habitat and by the feeding abilities of the fish in according to Wainwright and Richard (1995). The potential between the use of habitat, morphology, and foraging behavior not only interferes in the location and size of prey captured by fish, but these bias are also influenced by the change in the availability of prey to distinct fish ages and sizes (Lukoschek and McCormick, 2001).

As the gill nets observation intervals were relatively short (3 hours) it was possible to capture many individuals of $S$. hilarii with contents in their stomachs in lower digestion state. Thus it was noticed that this fish species swallows its prey whole. As Werner and Gilliam (1984) state, several papers have documented a positive correlation between body size of fish and size of prey items in a great number of taxa. In many cases the diets of carnivorous fish involve increase in the average size of prey and an increase of predator (Wainwright and Richard, 1995; Cantanhêde et al., 2008). In a closer morphometric view, it seems more acceptable to use maximum values of sizes of ingested prey for the respective class of size of predator, permitting the amplitude of maximum size of the species to be more clearly studied. Still in this context, a lesser observed parameter consists of the relationship between mouth vertical opening height and prey depth. The most elevated correlation between mouth height and prey depth indicates that the capacity of mouth opening and dorsal-ventral dimensions of prey are closely related. Few studies have measured either the diameter of the prey or diameter of mouth opening; instead, prey length and predator length are generally performed. This practice provokes the evaluation of mouth size in the diet order difficult, due to the fact that important features of the prey's morphology and the morphology of the feeding device of 
the predator are not directly considered (Wainwright and Richard, 1995).

By considering the main preys ingested by S. hilarii, the individuals of Astyasnax aff. fasciatus are proportionally more elongated than those of A. altiparanae, resulting to their larger standard lengths in relation to the predator. For A. altiparanae, the standard length values are relatively smaller due to a limitation of the predator's mouth opening by its larger relative height. Fish that show the habit of ingesting their prey as a whole have their mouth size as the limitation of prey's size to be ingested (Werner, 1974).

Based on the results of this study, in the Sorocaba river basin $S$. hilarii feeds mainly on Astyanax spp. When considering only the adult individuals a variation of the type of prey and feeding activity during the seasons may be observed, under strong influences of water temperature. A marked difference of prey characteristics may be also observed between adult and immature individuals. So, as it seems, this species explores the available resources from the environment as they are related in reference to their abundance, distribution and prey sizes, which may also be concerned to both the predator and the prey morphologies.

\section{Acknowledgements}

We thank to FAPESP and CAPES for the financial support. I thank also to the friends whose help was very important: André Teixeira da Silva, Érico Luis Hoshiba Takahashi, Leandro Müller Gomiero, Mauricio Cetra, Décio Soares (Secretaria do Meio Ambiente de Tatuí), Maria M. Aparecida and to the IBAMA for the authorization for fish collections.

\section{References}

AGOSTINHO, AA., GOMES, LC., SUZUKI, HI. and JULIOJÚNIOR, HF., 2004. Migratory fishes of upper Paraná Basin, Brasil. In CAROLSFIELD, J., HARVEY, B., ROSS, C., and BAER, A. (Eds.). Migratory fishes of South América: biology, fisheries, and conservation status. Washington: IDRC. p. 19-98.

BOZZA, AN. and HAHN, NS., 2010. Uso de recursos alimentares por imaturos e adultos de espécies piscívoras em uma planície de inundação neotropical. Biota Neotropica, vol. 10, no. 3, p. 217-225.

BRITSKI, HA., SATO, Y. and ROSA, ABS., 1988. Manual de Identificação de Peixes da Região de Três Marias, Brasília (com chave de identificação para os peixes da bacia do São Francisco). Brasília: CODEVASF. $115 \mathrm{p}$.

CANTANHÊDE, G., HAHN, NS., FUGI, R. and GUBIANI, ÉA., 2008. Alterations on piscivorous diet following change in abundance of prey after impoundment in a Neotropical river. Neotropical Ichthyology, vol. 6, no. 4, p. 631-636.

COSTELLO, MJ., 1990. Predator feeding strategy and prey importance: a new graphical analysis. Journal of Fish Biology, vol. 36, p. 261-263.

DEI TOS, C., GOMES, LC., AGOSTINHO, AA. and BATISTA, RP., 2009. Age, growth, mortality and yield per recruit of the dourado Salminus brasiliensis, Corumbá Reservoir, Goias State, Brazil. Neotropical Ichthyology, vol. 7, no. 2, p. 223-230.
FRITZ, ES., 1974. Total diet comparison in fishes by spearman rank correlation coeficients. Copeia, vol. 1, p. 210-214.

GRAÇA, WJ. and PAVANELLI, CS., 2007. Peixes da planicie de inundação do Alto Rio Paraná e Áreas Adjacentes. Maringá: Eduem. 241 p.

HAHN, NS., ANDRIAN, IF., FUGI, R. and ALMEIDA, VLL., 1997. Ecologia Trófica. In VAZZOLER, AEAM., AGOSTINHO, AA. and HAHN, NS. (Eds.). A planície de inundação do alto rio Paraná: aspectos fisicos, biológicos e socioeconômicos. Maringá: Eduem. p. 209-228.

HAMMER, Ø., HARPER, DAT. and RYAN, PD., 2001. PAST: Paleontological Statistics Software Package for Education and Data Analysis. Palaeontologia Electronica, vol. 4, no. 1, 9 p. Available from: <http://palaeo-electronica.org/2001_1/past/ issue1_01.htm>. Access in: 17 Oct. 2014.

HONJI, RM., 2007. Caracterização endócrina durante o ciclo reprodutivo da Tabarana Salminus hilarii (Characiformes: Characidae), em três ambientes distintos: natural, impactado e cativeiro. São Paulo: Universidade de São Paulo. 180 p. Masters Dissertation in Physiology.

HONJI, RM., MELO, PH., ARAUJO, BC., RODRIGUES-FILHO, JA., HILSDORF, AWS. and MOREIRA, R., 2011. Influence of spawning producer on gametes fertilization success in Salminus hilarii Valenciennes, 1850 (Teleostei: Characidae): implication for the conservation of this species. Neotropical Ichthyology, vol. 9 , no. 2, p. 363-370.

HYSLOP, EJ., 1980. Stomach content analysis: a review of methods and their applications. Journal of Fish Biology, vol. 17 , no. 4, p. 411-429.

JOBLING, M., 1993. Bioenergetics: feed intake and energy partitioning. In RANKIN, JC. and JENSEN, FB. (Eds.). Fish ecophysiology. London: CHAPMAN \& HALL.

KREBS, CJ., 1998. Ecological methodology. Menlo Park: Addison Wesley Longman. $620 \mathrm{p}$.

LIMA-JUNIOR, SE. and GOITEIN, R., 2001. A new method for the analysis of fish stomach contents. Acta Scientiarum, vol. 23 , no. 2, p. 421-424.

LIMA, FCT., MALABARBA, LR., BUCKUP, PA., SILVA, JFP., VARI, RP., HAROLD, A., BENINE, R., OYAKAWA, OT., PAVANELLI, CS., MENEZES, NA., LUCENA, CAS., MALABARBA, MCSL., LUCENA, ZMS., REIS, RE., LANGEANI, F., CASSATI, L., BERTACO, VA., MOREIRA, C. and LUCINDA, PNF., 2003. Genera incertae sedis in Characidae. In REIS, RE., KULLANDER, SO. and FERRARIS, CJ. (Eds.). Check list of the freshwater fishes of South and Central America. Porto Alegre: Edipucrs. p. 106-169.

LOWE-MCCONNELL, RHL., 1999. Estudos ecológicos de comunidades de peixes tropicais. São Paulo: Edusp. 535 p.

LUKOSCHEK, V. and MCCORMICK, M., 2001. Ontogeny of diet changes in a tropical benthic carnivorous fish Parupeneus barberinus (Mullidae): relationship between foraging behavior, habitat use, jaw size, and prey selection. Marine Biology, vol. 138, p. 1099-1113.

OLARTE, DR. and TAPHORN, DCB., 2006. Abundance, feeding and reproduction of Salminus sp. (Pisces: Characidae) from mountain streams of the Andean piedmont in Venezuela. Neotropical Ichthyology, vol. 4, no. 1, p. 73-79. 
PIET, GJ., 1998. Ecomorphology of a size-structured tropical freshwater fish community. Environmental Biology of Fishes, vol. 51, p. 67-86.

RAPOSO, RMG. and GURGEL, HCB., 2003. Variação da alimentação natural de Serrasalmus spilopleura Kner, 1860 (Pises, Serrasalmidae) em função do ciclo lunar e das estações do ano na lagoa de Extremoz, Rio Grande do Norte, Brasil. Acta Scientiarum Biological Sciences, vol. 25, no. 2, p. 267-272.

SMITH, WS., PETRERE JÚNIOR, M. and BARRELLA, W., 2003. The fish fauna in tropical rivers: The case of the Sorocaba river basin, São Paulo, Brazil. Revista de Biologia Tropical, vol. 51, no. 3-4, p. 769-782.

SMITH, WS., 2003. Os peixes do rio Sorocaba: a história de uma bacia hidrográfica. Sorocaba: TCM. 163 p.

Statsoft, 2005. Statistica (data analysis software system). Version 7.1. Available from: <www.statsoft.com>. Access in: 17 Oct. 2014.

TAKAHASHI, ELH., 2006. Ciclo Reprodutivo da tabarana, Salminus hilarii (Valenciennes, 1849) (Characidae, Salmininae) na Região do Baixo Sorocaba, SP. Jaboticabal: Universidade Estadual Paulista. 58 p. Masters Dissertation in Aquaculture.

VAZZOLER, AEAM., 1996. Biologia da reprodução de peixes teleósteos: teoria e prática. Maringá: Eduem. 169 p.
VILLARES-JÚNIOR, GA. and GOITEIN, R., 2006. Fish, Sorocaba basin, São Paulo State, Brazil. Check List, vol. 2, no. 3, p. 68-73.

VILLARES-JÚNIOR, GA., GOMIERO, LM. and GOITEIN, R., 2007. Relação peso-comprimento e fator de condição de Salminus hilarii Valenciennes 1850 (Osteichthyes, Characidae) em um trecho da bacia do rio Sorocaba, Estado de São Paulo, Brasil. Acta Scientiarum Biological Sciences, vol. 29, no. 4, p. 407-412.

VILLARES-JÚNIOR, GA., GOMIERO, LM. and GOITEIN, R., 2011. Biological aspects of Schizodon nasutus Kner, 1858 (Characiformes, Anostomidae) in the low Sorocaba river basin, São Paulo, Brazil. Brazilian Journal of Biology, vol. 71, no. 3, p. $763-770$.

WAINWRIGHT, PC. and RICHARD, BA., 1995. Predicting patterns of prey use from morphology of fishes. Environmental Biology of Fishes, vol. 44, p. 97-113.

WERNER, EE., 1974. The fish size, prey size, handing time relation in several sunfishes and some implications. Journal of the Fisheries Research Board of Canada, vol. 30, p. 787-797.

WERNER, EE. and GILLIAM, JF., 1984. The ontogenetic niche and species interactions in size-structured populations. Annual Review of Ecology Evolution and Systematics, vol. 15, p. 393-425.

ZAVALA CAMIN, LA., 1996. Introdução aos estudos sobre alimentação natural de peixes. Maringá: Eduen/Nupelia. 129 p. 